\title{
Game Techniques to Solve Students' Adjustment Problems: Evidance From Indonesia
}

\author{
Edy Irawan ${ }^{1}$, Syarifuddin Dahlan ${ }^{2}$, Een Y. Haenilah ${ }^{3}$, Tubagus Ali Rachman Puja Kesuma ${ }^{4}$, Albet \\ Maydiantoro $^{5}$, M. Arifki Zainaro ${ }^{6}$, Usastiawaty C.A.S Isnainy ${ }^{7}$, Eka Sofia Agustina ${ }^{8}$, Deri Ciciria ${ }^{9}$ \\ ${ }^{1,2,3}$ Doctor of Education Program, Teacher Training and Education Universitas Lampung, Soemantri \\ Brodjonegoro No 1 Lampung, Indonesia \\ ${ }^{4}$ Department of Social Science Educations, Institut Agama Islam Negeri (IAIN) Metro Metro City, \\ Indonesia \\ ${ }^{5}$ Department of Economic Education, University of Lampung Bandar Lampung City, Indonesia \\ ${ }^{6,7}$ Department of Nursing Management, Universitas Malahayati Bandar Lampung City, Indonesia \\ ${ }^{8}$ Department of Language Educations, University of Lampung Bandar Lampung City, Indonesia \\ ${ }^{9}$ Department of History Educations, STKIP PGRI Bandar Lampung, Bandar Lampung City, Indonesia
}

Email: edyirawan1280@gmail.com

Received: July 6., 2021 Revised: August 23, 2021. Accepted: August 25, 2021.

Published: August 27, 2021.

\begin{abstract}
This research is motivated by the problems of students who fail to achieve happiness in their lives; this is caused by the inability of students to make adjustments to all forms of change in maintaining survival. Efforts that can be made to overcome this problem are to provide group guidance services with game techniques. This study aims to test whether the game technique in group guidance services is effective for improving students' selfadjustment. The method used in this research is experimental research using Pretest-Posttest Control Group Design. The results showed that there was a change in the mean value at the pre-test of 93.43 for the experimental class and $\mathbf{9 2 . 5 7}$ for the control class and the mean value at the post-test of $\mathbf{1 5 1 . 6 4}$ for the experimental class and 98.71 for the control class. So that the mean value at the time of post-test increased by $\mathbf{5 8 . 2 1}$ for the experimental group and 06.14 for the control group. These changes mean that group guidance with game techniques is empirically proven to be effective in increasing student adaptation
\end{abstract}

Keywords - Group counseling; Game Techniques; Adjustment

\section{INTRODUCTION}

$\mathrm{A}$ dvances in science and technology that are increasingly sophisticated have an impact on human life. These changes raise life problems that are increasingly complex and difficult to overcome [1]. One example of the impact that occurs is the number of individuals who experience psychological disorders such as anxiety, despair, selfishness, stress, and mental disorders [2]. Finally, a person is unable to achieve happiness in his life caused by the inability of the individual to adapt to all forms of change in maintaining survival.

Adjustment is one of the important requirements for the creation of adolescent mental health [3]. Many adolescents suffer and are unable to achieve happiness in their lives because of their inability to adjust. In this regard, reveals failure adolescents in making adjustments will cause dangers such as being irresponsible and ignoring lessons, aggressive attitudes and very confidence in them, feelings of insecurity, feeling like going home if they are far from an unfamiliar environment, and feelings of giving up [4]. Unable to make adjustments, one of which comes from the psychological atmosphere of the family such as a family rift. This is as evidenced in Ritter's research [5], that adolescents who live in families that experience "cracks", will experience emotional problems look at him the tendency huh Great for anger, aloof, in addition to lack of sensitivity to social acceptance, lack of 
self-confidence, lack of self-restraint and more anxiety than adolescents who live in normal households.

A person's self-adjustment ability begins when entering adolescence both psychologically and physiologically [6]. Adolescence is a period of transition (transition) from childhood to adolescence which is characterized by accelerated physical, mental development, emotional, and social that takes place in the second period of life [7]. So that at this time adolescents are often referred to as a turbulent period and a time to seek self-identity, where adolescents can no longer use the attitudes and guidelines of childhood. Children, but at the same time do not have a new way of life [8].

Adjustment is a demand for each individual to be accepted in society and a process that involves mental and behavioral responses to meet needs that do not conflict with societal norms [9]. Therefore, individuals, especially students in schools, need to have the ability to adapt to be able to interact well with other individuals [10]. However, not all individuals can adapt well, there are individuals or students who are not able to adjust and follow the rules that exist in their social environment (Tangney, Boone, \& Baumeister, 2018). Facts such as skipping school, inability to complete school assignments [11], and other forms of deviation often occur.

School as a social environment where students interact should be able to create and provide a psychological atmosphere that can encourage the behavior of each student [12]. The pattern of behavior in question is that students are able to interact harmoniously, intimately, honestly, behave politely, and are able to obey school rules so that they can be accepted in their environment [13]. Junior high school students are classified as teenagers who are undergoing a process of development and growth [7]. Adolescents are often faced with various problems that require the ability to reach the level of abstract thinking to analyze problems and find the best solution [14]. For example, being able to understand the material presented by the teacher during the process of teaching and learning activities and being able to realize it is not in meaning but in practice.

Based on the results of the field study, it was found data explaining that students still tend to not be able to control their emotions well during the teaching and learning process by showing behaviors such as truancy, speaking impolitely, withdrawing from the environment, and not doing school assignments. These symptoms are caused by several factors, one of which is the possibility of students not being able to adapt. These symptoms result in feelings of insecurity, not daring to try new things, feeling stupid, low self-esteem, feeling worthless, and feeling unworthy of success and pessimism. Finally the symptoms resulted in learning achievement in school. This is in line with what was expressed by [15] that the symptoms that can give an indication of difficulties in adjusting, include: rebellious behavior, irritability, likes to lie, likes to play truant, talks aggressively, and likes to offend others, often defends them by using rationalization, likes to be silent and silent, and likes to play against each other.

Looking at the problems above, the efforts that have been made by schools related to increasing student self-adjustment have not been able to solve the existing problems. So far, the provision of services provided by counselors has not changed and developed according to the needs of students at school, so the actual problems have not been resolved properly.

Departing from the problems above, it is necessary to conduct guidance and counseling efforts in order to improve student behavior so that they are able to make adjustments to the environment at school. Because if no adjustment efforts are made to students, it will result in not achieving educational goals [10].

One of the efforts that can be done is to provide Group Guidance services. Group guidance is a service technique provided to students to prevent the development of problems or difficulties in students that can be taken with various approaches [16]. Another opinion suggests that group guidance is an effort to help someone in a group atmosphere so that someone can understand themselves, prevent problems, and be able to improve them by utilizing group dynamics so that a person can undergo optimal development [17]. group guidance starts from informative to therapeutic [16], namely guidance and counseling that reaches the level of problemsolving, meanwhile the techniques that can be done in group guidance are providing information, group discussions, problem-solving, games, field trips, and socio-drama [18].

Each of the above group guidance techniques has advantages in its implementation. Likewise, group guidance in the form of games is the aim of this research. The game is a harmonious blend of group guidance because playing activities can train students both cognitively, affectively, and psychomotor [19]. So that it can train students to explore, exercise imagination, provide opportunities to connect with other people, and feel unsaturated in the process of learning new skills and knowledge [18].

This study aims to help and grow students' skills in adjusting to the environment through games in group guidance services. Based on the exposure and literature study conducted, the authors assume that the game technique in group guidance services can improve students' self-adjustment.

\section{RESEARCH METHODOLOGY}

The method used in this research is quasi experimental research using Pretest-Posttest Control Group Design. The data was taken from the Junior High Schools in Pringsewu Regency. The population in this study was all seventh-grade students consisting of 9 classes with a total of 315 students of SMPN 2 Pringsewu. The sampling technique used in this study was simple random sampling. The data collectors were a questionnaire in the form of a checklist for case problems, a questionnaire on the identification of students' adjustment to the school environment for the pre-test, and group game data for the post-test. 
The games that practiced were [20] one-way and two-way communication games, aimed at being able to understand the importance of understanding interaction in order to achieve good communication in establishing friendships; (2) the game my close friend, aims to analyze self-strength with the comparison of the results of analysis of friends; [21] selfmelting games, aimed at fostering mutual respect for one another in establishing togetherness; [22] police and thief games, aimed at training positive attitudes to want to actively participate in participating in activities; (5) creative space games, aimed at fostering respect for the common interest and still paying attention to existing regulations; and [20] selfevacuation games, aimed at helping students to create strategies in achieving a goal. We present it in detail in table 1 below.

Table 1 Games Syntax

\begin{tabular}{|c|c|c|c|c|c|c|}
\hline $\begin{array}{l}\mathbf{N} \\
\mathbf{0}\end{array}$ & $\begin{array}{l}\text { Game } \\
\text { Name }\end{array}$ & $\operatorname{Aim} / s$ & Game Procedure & $\begin{array}{l}\text { Resource/ } \\
\text { Materials }\end{array}$ & $\begin{array}{c}\text { Time } \\
\text { Allocation }\end{array}$ & Questions to Discuss \\
\hline 1 & $\begin{array}{l}\text { One-way } \\
\text { and two- } \\
\text { way } \\
\text { communic } \\
\text { ation }\end{array}$ & $\begin{array}{l}\text { Students are } \\
\text { able to } \\
\text { understand the } \\
\text { importance of } \\
\text { understanding } \\
\text { interaction in } \\
\text { order to achieve } \\
\text { good } \\
\text { communication } \\
\text { in establishing } \\
\text { friendships }\end{array}$ & $\begin{array}{l}\text { Two volunteers were asked to } \\
\text { demonstrate the activity: one } \\
\text { volunteer gave instructions } \\
\text { and the other carried out the } \\
\text { instructions. The instructions } \\
\text { are in the form of a sequence } \\
\text { of drawing one object (one- } \\
\text { way communication: } \\
\text { volunteers are not allowed to } \\
\text { ask or ask other participants), } \\
\text { and the next activity is two- } \\
\text { way communication } \\
\text { (volunteers can ask questions } \\
\text { and explanation) so that } \\
\text { reciprocity occurs among } \\
\text { others). }\end{array}$ & $\begin{array}{l}\text { Relevant } \\
\text { pictures and } \\
\text { instructions }\end{array}$ & 45 minutes & $\begin{array}{l}\text { \$ Do you understand } \\
\text { the source that is } \\
\text { conveyed? } \\
\text { \$ Why is one-way } \\
\text { communication so } \\
\text { difficult to convey } \\
\text { compared to two- } \\
\text { way } \\
\text { communication? } \\
\text { \$ What strategies will } \\
\text { you use to make } \\
\text { communication } \\
\text { more effective? } \\
\text { \$ What lessons did you } \\
\text { learn from this } \\
\text { activity? }\end{array}$ \\
\hline 2 & $\begin{array}{l}\text { My close } \\
\text { friend }\end{array}$ & $\begin{array}{l}\text { Students are } \\
\text { able to analyze } \\
\text { their own } \\
\text { strengths by } \\
\text { comparing the } \\
\text { results of their } \\
\text { friends' analysis }\end{array}$ & $\begin{array}{l}\text { Participants are asked to form } \\
\text { small groups consisting of five } \\
\text { people and please sit in a } \\
\text { circle facing each other and } \\
\text { relax by holding the paper and } \\
\text { pencil and tongs that have } \\
\text { been given by being asked to } \\
\text { write down at least three of } \\
\text { their friends' strengths that can } \\
\text { support them in establishing } \\
\text { friendly relations in turns, } \\
\text { write honestly, if you have } \\
\text { written down the three } \\
\text { strengths of your friends, } \\
\text { please show them to your } \\
\text { friends by standing up and } \\
\text { sticking them to your chest so } \\
\text { you can see them. }\end{array}$ & $\begin{array}{l}\text { HVS paper, } \\
\text { pen, tongs }\end{array}$ & 45 minutes & $\begin{array}{l}\text { \$ Do you do this } \\
\text { activity sincerely } \\
\text { and honestly? } \\
\text { \$ Have you found at } \\
\text { least three of your } \\
\text { friend's strengths? } \\
\text { \$ Does anyone have } \\
\text { difficulty writing } \\
\text { down your friend's } \\
\text { strengths? } \\
\text { \$ How do you view the } \\
\text { results of your } \\
\text { friends' assessment } \\
\text { of you? } \\
\text { \$ When will you start } \\
\text { growing these } \\
\text { strengths and what } \\
\text { are your strategies } \\
\text { for implementing } \\
\text { them? }\end{array}$ \\
\hline 3 & $\begin{array}{l}\text { Self- } \\
\text { Melting }\end{array}$ & $\begin{array}{l}\text { Cultivate mutual } \\
\text { respect for each } \\
\text { other in } \\
\text { establishing } \\
\text { togetherness }\end{array}$ & $\begin{array}{l}\text { The guide asked all } \\
\text { participants to stand up. To } \\
\text { start this game, the guide } \\
\text { instructed participants to walk } \\
\text { slowly, scatter and look at the }\end{array}$ & $\begin{array}{l}\text { Instructions } \\
\text { from the } \\
\text { researcher to } \\
\text { the students } \\
\text { who will }\end{array}$ & 45 minutes & $\begin{array}{l}\text { \$ Have you done this } \\
\text { activity according } \\
\text { to the instructions } \\
\text { given? } \\
\text { \$ When do you feel }\end{array}$ \\
\hline
\end{tabular}




\begin{tabular}{|c|c|c|c|c|c|}
\hline & & & $\begin{array}{l}\text { floor with full concentration, } \\
\text { imagining you were now like } \\
\text { an old person aged } 80 \text { years } \\
\text { (for } 10 \text { seconds). Then the } \\
\text { guide instructed participants to } \\
\text { look in all directions and } \\
\text { pretended if they met an older } \\
\text { person greet by nodding their } \\
\text { head, now gradually you were } \\
\text { younger age } 70 \text { years who } \\
\text { were fresher and greet those } \\
\text { who were older by shaking } \\
\text { hands. Now you were much } \\
\text { younger like a fit and healthy } \\
\text { 50-year-old person who was } \\
\text { full of enthusiasm and strength } \\
\text { and rebuked those around you } \\
\text { indiscriminately age. Now you } \\
\text { were like a } 30 \text {-year-old who } \\
\text { could move quickly and greet } \\
\text { them with a gentle greeting. } \\
\text { Now you stop moving and } \\
\text { stand straight where you are, } \\
\text { suddenly you become a happy } \\
13 \text {-year-old person and run } \\
\text { quickly to approach the people } \\
\text { around you without greeting } \\
\text { and at will. }\end{array}$ & $\begin{array}{l}\text { perform this } \\
\text { game }\end{array}$ & $\begin{array}{l}\text { most comfortable } \\
\text { and when do you } \\
\text { feel least } \\
\text { comfortable? what } \\
\text { caused it? } \\
\text { \& Do you feel that life } \\
\text { is very valuable } \\
\text { when you can } \\
\text { respect each other? } \\
\text { What strategies will } \\
\text { you take to } \\
\text { maintain mutual } \\
\text { respect for each } \\
\text { other? } \\
\text { \%o what extent can } \\
\text { you respect each } \\
\text { other? } \\
\text { \& What benefits can } \\
\text { you take from this } \\
\text { activity? }\end{array}$ \\
\hline 4 & $\begin{array}{l}\text { Police and } \\
\text { thieves }\end{array}$ & $\begin{array}{l}\text { Students are } \\
\text { able to be } \\
\text { positive to want } \\
\text { to actively } \\
\text { participate in } \\
\text { participating in } \\
\text { activities }\end{array}$ & $\begin{array}{l}\text { The guide asked participants } \\
\text { to form a big circle by holding } \\
\text { hands, keep the distance } \\
\text { between participants wearing } \\
\text { hula hoops and those wearing } \\
\text { sarongs is about 5-7 } \\
\text { participants, hula hoops (as } \\
\text { police) and sarongs (as } \\
\text { thieves), using them as a sling } \\
\text { (from the shoulder) to the } \\
\text { waist). Participants must be } \\
\text { able to move the hula hoop } \\
\text { and the holster next to it as } \\
\text { quickly as possible without } \\
\text { letting go of their handgrip, } \\
\text { and thieves can be caught } \\
\text { when the hula hoop and } \\
\text { holster are on the same person. } \\
\text { This game is played repeatedly } \\
\text { so that all participants have the } \\
\text { same opportunity. }\end{array}$ & $\begin{array}{l}\text { Hula-hoop and } 45 \text { minutes } \\
\text { sarong }\end{array}$ & $\begin{array}{l}\text { \# Have you carried out } \\
\text { the activities } \\
\text { according to the } \\
\text { instructions? } \\
\text { \& Anyone having } \\
\text { trouble playing this } \\
\text { game? } \\
\text { \& What do you feel } \\
\text { and think when } \\
\text { you are caught } \\
\text { with two objects at } \\
\text { once? } \\
\text { \& Are your friends } \\
\text { enough to help in } \\
\text { doing this activity? } \\
\text { \& What obstacles did } \\
\text { you encounter } \\
\text { during this } \\
\text { activity? } \\
\text { \& What strategies will } \\
\text { you take to } \\
\text { overcome } \\
\text { problems during } \\
\text { this activity? }\end{array}$ \\
\hline 5 & Creative & Students are & The guide asked participants & 45 minutes & \# How do you feel \\
\hline
\end{tabular}




\begin{tabular}{|c|c|c|c|c|c|}
\hline & space & $\begin{array}{l}\text { able to be } \\
\text { respectful of the } \\
\text { common good } \\
\text { and still pay } \\
\text { attention to } \\
\text { existing } \\
\text { regulations }\end{array}$ & $\begin{array}{l}\text { to form groups of } 5 \text { members } \\
\text { each; each group is distributed } \\
\text { paper and raffia to create a } \\
\text { creative space in accordance } \\
\text { with the instructions given } \\
\text { while adhering to the } \\
\text { applicable rules, in which the } \\
\text { creative space is a form of } \\
\text { building space carried out with } \\
\text { instructions. From a guide that } \\
\text { can be in the form of a } \\
\text { trapezoid, rectangle, triangle, } \\
\text { and square by utilizing the } \\
\text { paper and raffia rope. }\end{array}$ & paper & $\begin{array}{l}\text { after playing this } \\
\text { game? } \\
\text { \& Why is there a wake- } \\
\text { up space that is } \\
\text { fast and slow in } \\
\text { completing it? } \\
\text { \& What if there are } \\
\text { groups that do not } \\
\text { follow the rules } \\
\text { that have been } \\
\text { determined? } \\
\text { \& What are the group's } \\
\text { strengths and } \\
\text { weaknesses in } \\
\text { building the } \\
\text { creative space? } \\
\text { \&hat strategies will } \\
\text { you take to } \\
\text { anticipate this } \\
\text { weakness? }\end{array}$ \\
\hline 6 & $\begin{array}{l}\text { Self- } \\
\text { Evacuation }\end{array}$ & $\begin{array}{l}\text { Helping students } \\
\text { to create } \\
\text { strategies in } \\
\text { achieving a goal }\end{array}$ & $\begin{array}{l}\text { Participants are divided into } \\
\text { several groups and each group, } \\
\text { in turn, will get } 3 \text { carpets, } 1 \\
\text { carpet serves as a pedestal for } \\
\text { you and try not to touch your } \\
\text { feet to the toxic waste, and } 2 \\
\text { carpets as a base to move that } \\
\text { will help you reach the finish } \\
\text { line in achieving The goal is to } \\
\text { place } 2 \text { carpets alternately in } \\
\text { front of your position to be } \\
\text { climbed than the carpet that } \\
\text { was taken and placed in front } \\
\text { of you again and so on until } \\
\text { the finish line, all members } \\
\text { may not make a sound at all } \\
\text { only allowed to move their } \\
\text { limbs. }\end{array}$ & $\begin{array}{l}3 \text { pieces of } \\
\text { carpet, plastic } \\
\text { rope }\end{array}$ & $\begin{array}{l}\text { \# Have you done this } \\
\text { activity according } \\
\text { to the instructions } \\
\text { that have been } \\
\text { given? } \\
\text { \& Can group } \\
\text { cohesiveness be } \\
\text { built easily? } \\
\text { \# What difficulties did } \\
\text { you experience } \\
\text { when reaching the } \\
\text { finish line to } \\
\text { achieve a goal? } \\
\text { \# What strategies do } \\
\text { you use to quickly } \\
\text { and easily reach } \\
\text { the finish line? } \\
\text { \& What should you do } \\
\text { to keep your } \\
\text { current group } \\
\text { proud? } \\
\text { \& What lessons can } \\
\text { you take from this } \\
\text { game? }\end{array}$ \\
\hline
\end{tabular}

Furthermore, to determine the effectiveness of using game techniques in group guidance to improve student adjustment in the school environment, it was carried out using the Wilcoxon Signed Ranks Test. By comparing the gain score, namely the difference in scores between the post-test and the pre-test of students' adjustment in the school environment, we could have the results of the analysis obtained a hypothesis. The criteria for testing the hypothesis are Ho. = game techniques in group guidance are not effective for improving students' selfadjustment, $\mathrm{H} 1$. = game techniques in group guidance are effective for improving students' self-adjustment. The basic criteria for decision making are 1 ) If $t$ count $>t$ table, then Ho is rejected and $\mathrm{H} 1$ is accepted; and 2) If $\mathrm{t}$ count $<\mathrm{t}$ table, then $\mathrm{Ho}$ is accepted and $\mathrm{H} 1$ is rejected.

\section{RESULTS}

Student Adjustment Level before Giving Treatment

General description of all aspects of adjustment used as research in each group, both experimental group, and control group in the low level of adjustment category, with the aim of knowing the initial data on the results of the distribution of the student's self-adjustment scale before being given treatment in 
the form of game techniques in group guidance to the group experimental and control groups, with an average value obtained of 93.43 for the experimental group and 92.57 for the control group. In more detail, the calculation of the criteria for the description of students' self-adjustment obtained before the implementation of game techniques in group guidance on each aspect with categorization can be seen in Table 2 below.

Table 2 Level of Student Adjustment in Each Aspect before Giving Treatment

\begin{tabular}{|c|c|c|c|c|c|c|}
\hline \multirow[t]{2}{*}{ Aspects } & \multirow[t]{2}{*}{ Category } & \multirow[t]{2}{*}{ Range } & \multicolumn{2}{|c|}{$\begin{array}{l}\text { Experimental } \\
\text { Group }\end{array}$} & \multicolumn{2}{|c|}{$\begin{array}{l}\text { Control } \\
\text { Group }\end{array}$} \\
\hline & & & $\mathbf{F}$ & $\overline{\bar{x}}$ & $\mathbf{F}$ & $\overline{\bar{x}}$ \\
\hline \multirow[t]{3}{*}{ Ability to establish friendly relations with friends at school } & High & $45<X \leq 60$ & 0 & \multirow{3}{*}{29,29} & 0 & \multirow{3}{*}{28,43} \\
\hline & Medium & $30<X \leq 45$ & 6 & & 4 & \\
\hline & Low & $15 \leq X \leq 30$ & 8 & & 10 & \\
\hline \multirow[t]{3}{*}{$\begin{array}{l}\text { Ability to be respectful towards teachers, principals, and } \\
\text { school staff }\end{array}$} & High & $27<X \leq 36$ & 0 & \multirow{3}{*}{16,50} & 1 & \multirow{3}{*}{17,29} \\
\hline & Medium & $18<X \leq 27$ & 8 & & 7 & \\
\hline & Low & $9 \leq X \leq 18$ & 6 & & 6 & \\
\hline \multirow[t]{3}{*}{ Active participation in following school activities } & High & $30<X \leq 40$ & 0 & \multirow{3}{*}{19,36} & 0 & \multirow{3}{*}{17,93} \\
\hline & Medium & $20<X \leq 30$ & 5 & & 2 & \\
\hline & Low & $10 \leq X \leq 20$ & 9 & & 12 & \\
\hline \multirow[t]{3}{*}{ Be respectful and willing to accept school rules } & High & $21<X \leq 28$ & 0 & \multirow{3}{*}{12,36} & 0 & \multirow{3}{*}{11,57} \\
\hline & Medium & $14<X \leq 21$ & 3 & & 2 & \\
\hline & Low & $7 \leq X \leq 14$ & 11 & & 12 & \\
\hline \multirow[t]{3}{*}{ Assist in realizing school goals } & High & $27<X \leq 36$ & 0 & \multirow{3}{*}{15,93} & 1 & \multirow{3}{*}{17,36} \\
\hline & Medium & $18<X \leq 27$ & 1 & & 2 & \\
\hline & Low & $9 \leq X \leq 18$ & 13 & & 11 & \\
\hline
\end{tabular}

Table 2 above shows that the aspects of self-adjustment include the first aspect, namely the ability to establish friendly relations with friends at school, with the mean value obtained at 29.29 for the experimental group and 28.43 for the control group. In the second aspect, namely the ability to be respectful towards teachers, principals, and school staff, the mean score is $\mathbf{1 7 . 5 0}$ for the experimental group and 17.29 for the control group. In the third aspect, namely actively participating in school activities, the average value was 19.36 for the experimental group and 17.93 for the control group. In the fourth aspect, being respectful and willing to accept school rules, the mean value of is 12.36 for the experimental group and 11.57 for the control group. In the fifth aspect, which is helping in realizing school goals, the average value is 15.93 for the experimental group and 17.36 for the control group.

In detail, the five aspects are divided into three categories, namely high, medium and low. The high criteria in the aspect of the ability to establish friendly relations with friends at school are at a score above 46, none, the moderate criteria are at scores above 31 to 45 , totaling 6 students, and the low category being at a score of 15 to 30 totaling 8 students for the experimental group., while the control group in the high category did not exist, there were 4 students in the medium category and 10 students in the low category.

The high criteria in the second aspect, namely the ability to be respectful towards teachers, principals, and school staff are at a score above 26 , none, the moderate criteria are at scores above 17 to 25 , totaling 6 students and low criteria at a score of 8 to 16 total 8 students. For the experimental group, while for the control group in the high category there were 1 student, 7 students in the medium category and 6 students in the low category.

For the high criteria in the third aspect, namely active participation in school activities, there are no scores above 31 , 
the moderate criteria are at scores above 21 to 30 , totaling 3 students, and low criteria at scores 10 to 20 totaling 11 students for the experimental group while for the control group in the high category there were no, there were 2 students in the medium category and 12 students in the low category.

The high criteria in the fourth aspect, namely being respectful and willing to accept school rules are at a score above 22 , there are none, the medium criteria are at scores above 15 to 21 , totaling 3 students, and low criteria at a score of 7 to 14 total 11 students for the experimental group., while the control group in the high category did not exist, there were 2 students in the medium category and 12 students in the low category.

As for the high criteria in the fifth aspect, which is helping in realizing schools, there are no scores above 28 , the medium criteria are at scores above 19 to 27 which amount to 1 student and the low criteria at scores 9 to 18 are 13 students for the experimental group, while for the control group in the high category there was 1 student, in the medium category there were 2 students and those in the low category were 11 students. This means that from the explanation it is known that most of the students' self-adjustment scores from all aspects are in a low category before giving treatment, where students are said to not have the ability to adjust at school by showing that they have not been able to establish friendly relations with friends at school such as have not been able to accept friends as they are and have not been able to control emotions and maintain friendly relations that have been fostered, have not been able to be respectful towards teachers, principals, and school staff as in speaking politely and politely and maintaining an attitude when meeting anyone have not been able to actively participate in school activities, have not had the attitude of respect and willing to accept school rules, and have not been able to assist in realizing school goals such as maintaining a good name and being involved in school.

Student Adjustment Level at Pre-test and Post-test

The following describes the changes in the level of student adjustment from the results of the study with the scores obtained during the pre-test and post-test. The acquisition of the level of student adjustment is presented in Table 3 below.

Table 3 Changes in Student Adjustment Level Scores

\begin{tabular}{llcccc}
\hline No & Name & Pre-test & Post-test & Score change & Explanation \\
\hline 1 & BN & 96 & 153 & 57 & Increase \\
\hline 2 & DK & 98 & 159 & 61 & Increase \\
\hline 3 & FR & 96 & 146 & 50 & Increase \\
\hline 4 & HD & 72 & 156 & 84 & Increase \\
\hline 5 & MS & 84 & 157 & 73 & Increase \\
\hline 6 & PR & 97 & 154 & 57 & Increase \\
\hline 7 & RS & 92 & 138 & 46 & Increase \\
\hline 8 & RF & 97 & 151 & 54 & Increase \\
\hline 9 & SA & 97 & 144 & 47 & Increase \\
\hline 10 & TF & 97 & 152 & 55 & Increase \\
\hline 11 & TN & 93 & 156 & 63 & Increase \\
\hline 12 & VN & 97 & 153 & 56 & Increase \\
\hline 13 & WW & 95 & 153 & 58 & Increase \\
\hline 14 & ZH & 97 & 151 & 54 & Increase \\
\hline
\end{tabular}

Table 3 above shows us that all students who participated in game technique activities in group guidance experienced an increase in score changes from before giving treatment to increasing after giving treatment, this shows that it is quite effective to use game techniques in group guidance to improve student adjustment.
The increase in overall student self-adjustment scores can be seen through changes in the mean scores of pre-test and post-test results in the experimental group and the control group. The following is the average value of students' selfadjustment scores in Table 4 below.

Table 4 Mean Values of Pretest and Posttest Experiment and Control Group Students' Self-Adjustment

\begin{tabular}{clc}
\hline Measurements & \multicolumn{1}{c}{ Group } & Average \\
\hline \multirow{2}{*}{ Pre-test } & Experimental group & 93,43 \\
\cline { 2 - 3 } & Control group & 92,57 \\
\hline \multirow{2}{*}{ Post-test } & Experimental group & 151,64 \\
\cline { 2 - 3 } & Control group & 98,71 \\
\cline { 2 - 3 } & &
\end{tabular}

Table 4 above shows a change in the average score of students during the pre-test and post-test in the experimental group and the control group. The mean value at the pre-test was 93.43 for the experimental class and 92.57 for the control class and the mean value at the post-test was 151.64 for the experimental class and 98.71 for the control class. So that the mean value at the time of the post-test increased by 58.21 for the experimental group and 6.14 for the control group. 
Meanwhile, to see further the comparison of the mean value between the experimental group and the control group before and after giving treatment in the form of game techniques in group guidance can be seen in Table 5 below.

Table 5 Comparison of the Average Value of Student Self-Adjustment in General Before and After Treatment

\begin{tabular}{lrrrc}
\hline \multicolumn{1}{c}{ Aspects } & \multicolumn{2}{c}{ Experimental Group } & \multicolumn{2}{c}{ Control Group } \\
\cline { 2 - 5 } & Pre-test & Pots-test & Pre-test & Post-test \\
\hline Ability to establish friendly relations with friends at school & 29,29 & 45,71 & 28,43 & 30,29 \\
\hline $\begin{array}{l}\text { Ability to be respectful towards teachers, principals, and school } \\
\text { staff }\end{array}$ & 16,50 & 26,07 & 17,29 & 18,00 \\
\hline Active participation in following school activities & & & & \\
\hline Be respectful and willing to accept school rules & 19,36 & 30,00 & 17,93 & 18,86 \\
\hline Assist in realizing school goals & 12,36 & 21,43 & 11,57 & 13,5 \\
\hline
\end{tabular}

\section{DISCUSSION}

The results of the research that have been carried out show that the results of the adjustment of all seventh-grade students of SMP Negeri 2 Pringsewu, totaling 315 students, are generally at a moderate level. From all these students, data obtained that the students identified as having a high selfadjustment category were 111 students (35.24\%). While students who have self-adjustment are in a low category, only 28 students $(9.21 \%)$, and those who are in the medium category are 176 students $(55.56 \%)$. Although the results of the study showed that students' self-adjustment was in the moderate category, in general, seventh-grade students of SMP Negeri 2 Pringsewu had not been able to achieve optimal adjustment.

When viewed from the stages of development, students who are the object of research fall into the category of adolescent age, namely early adolescence. Adolescence is a period of transition (age 15-21 years). Junior high school students are in a transitional stage (aged 12-15 years) from childhood to adolescence which is marked by the acceleration of physical, mental, social, emotional, and social development that takes place in the second period of life or a period of searching for true and true identity. . So that in adolescents there is a process of adjusting to the standards and habits of groups in their environment. However, not all individuals can make changes that occur within themselves during adolescence that require a person to make adjustments within him, accept changes for himself, and form a new "sense of self" about who he is to prepare for the future [13].

With the reinforcement of the statement above, it becomes a natural thing if the seventh-grader of junior high school students still have problem in adjustments that are in the low category, considering that junior high school students are a period of identity search where teenagers are in a continuum between identity and identity confusion.

This is also supported by the statement that students at the junior high school (SMP) level are generally in the age range between the ages of 12/13-15 years, in the context of individual developmental psychology, they are in the early adolescent phase [23]. This developmental phase is known as a period of storm and stress, frustration and suffering, conflict and adjustment crisis, dreams and daydreams about love, and feelings of being alienated from the socio-cultural life of adults [13].

Adolescence is the peak of emotionality, namely high emotional development [24]. In early adolescence, his emotional development shows a very strong sensitive and reactive nature to various social events or situations, his emotions are negative and temperamental (irritable/angry, or easily sad/moody). The statement becomes the basis that the statement item with the lowest percentage is achieved by the ability item to calm down in dealing with problems.

Of the total population, only 111 students (35.24\%) had their self-adjustment achievement in the high category. So in general, students still need development towards achieving high self-adjustment.

Students are said to be in the category of high selfadjustment or able to adapt well if students are able to perfectly meet their needs without exaggerating one and reducing the other by not harming themselves and being responsible for the environment in which the individual lives. Because of self-adjustment aims is to change individual behavior so that there is a more appropriate relationship between oneself and the environment. So, on the basis of this understanding, it can be given a limitation that the ability of human adjustment in social relations cannot be separated from the input or criticism, and emotional control, all of which are attitudes to foster good relationships. The good relationship is when student is able to fulfill the need of both sides, like care, protect, and help each other. The success of a person in a relationship is also shown how a person's intention to learn to improve him is to be able to adapt to his environment. Giving feedback in relationships is done with good communication that can provide warmth and closeness in maintaining relationships with the environment so that students are able to make adjustments to themselves and their environment. This is in line with the opinion of Noviandari and Mursidi adding that there are several principles regarding self-adjustment as stated below:

Self-adjustment is a process of aligning the individual's own 
condition with the environment as an object/stimulant through learning activities

In the process of adjustment, there is always an interaction between the impulses from within the individual with a stimulus or the demands of the social environment

To carry out self-adjustment, a process of understanding oneself and the environment is needed, so that harmony, conformity, compatibility, or harmony between self and environment is realized

Self-adjustment proceeds and develops dynamically in accordance with the dynamics of the environment and the development of individual desires that are autoplastic and alloplastic. [4]

Adaptation also has the meaning of a process of organism activity to overcome an obstacle and satisfy needs and establish a harmonious relationship with the physical and social environment [25]. Therefore, counselors tend to help students in adjusting to those in the low category who are considered unable to establish harmonious relationships with the physical and social environment by using various game techniques in groups because group games are social. So that students can be directed to positive self-adjustment. A person is said to have positive self-adjustment if he has: [20] good physical health, namely physical health that is free from health problems such as headaches, digestive disorders due to appetite problems or psychological factors; (2) psychological comfort, namely psychological comfort free from psychological symptoms such as obsessive-compulsive, anxiety and depression; [21] work efficiency, namely the ability of individuals to utilize their work and social capacities; and [22] social acceptance, namely the acceptance of individuals by other individuals, groups, communities when these individuals interact because they comply with applicable norms and values [26].

Students whose self-adjustment is low from the results of the study indicate that these students have not been able to adjust well such as still showing behavior that is often silent and moody, students withdraw from the environment, and cannot establish friendly relations at school which is marked on several aspects in terms of not being able to able to establish friendly relations with friends, have not been able to be respectful with others, have not been able to be respectful and willing to accept school rules, do not yet have a positive attitude in helping to realize school goals, so it is necessary to provide techniques in guidance and counseling.

The results of the study identified that most of the students had not been able to adjust well. This happens because of the tendency that most children directly or indirectly often daydream, remain silent and isolate themselves from their surroundings while at school [27]. The lack of self-adjustment will have a negative impact if it is not immediately addressed, including marked by various forms of behavior that go awry, undirected, emotional, unrealistic, aggressive, and so on. According to Bender and Lange, there are four forms of reactions in the wrong adjustment, including:
Defense reaction/flight from self is an adjustment made by individuals to protect their ego's security which sometimes threatens themselves, such as compensation, sublimation, and projection.

Aggressive reactions and delinquency, namely adjustments made by individuals in order to fight against conditions that frustrate the fulfillment of their needs or desires, such as verbal behavior (saying harshly, fighting, calling bad names, rude answers, hurtful words) heart, and sharp criticism), and nonverbal behavior (rejecting or violating, fighting, rebelling, fighting, dominating others, and killing). While the form of delinquency behavior is considered as an effort to meet needs, and reduce tension, frustration, and other conflicts.

Escape reactions from reality, namely adjustments made by individuals to defend themselves against environmental pressures, or threats from the environment, such as: fantasizing or daydreaming, sleeping a lot or uncontrolled sleeping habits, drinking alcohol, suicide, becoming addict's marijuana, and regression.

Pathological adjustments (flight into illness), namely adjustments made by individuals because they are experiencing pathological adjustments and need to get special and clinical care because they include neuroses (ie, relatively mild personality disorders, as a result of chronic tension, conflict, personal frustration and disability expressed in the behavioral symptoms of the syndrome) and psychosis (a serious form of disorder, in which the sufferer loses contact with the real world which is reflected in disturbances in perception, thinking, emotion, and personal orientation). [28]

For students who are said to be successful in adapting, the process of the occurrence of these behaviors does not appear suddenly, but from the learning process from their social environment which is used as a model, be it from the family, school, or community environment. Because the adjustment that individuals have is produced through their daily interactions and observations with the people around them in the real world, not unilaterally satisfying one impulse without regard to the other impulses. This is in line with the opinion of Cass and Radl which states that behavior in students' selfadjustment can be changed by the adjustment process that occurs in the surrounding environment [29]. So that it can solve social problems and increase students' independence in dealing with life.

\section{V.CONCLUSION}

In general, the self-adjustment ability of grade VII students is in the low category in the five aspects of self-adjustment, both in terms of the ability to establish friendly relations with friends at school, the ability to be respectful towards teachers, principals, and school staff, active participation in school activities, attitude respect and accept school rules, and help achieve school goals. The ability to adapt has an important role in building a harmonious relationship with the physical and social environment. Game techniques in group guidance are effectively used to improve students' self-adjustment; it is 
proven that the five aspects of self-adjustment have increased significantly after being given treatment in the form of game techniques in group guidance refers to change in the mean value at the pre-test of 93.43 for the experimental class and 92.57 for the control class and the mean value at the post-test of 151.64 for the experimental class and 98.71 for the control class.

\section{ACKNOWLEDGMENT}

The author expresses his deepest gratitude to all those who have helped in the completion of this article. Especially to SMP N 2 Pringsewu which has allowed the author to carry out this research.

\section{References}

[1] Bor, W., et al., Are child and adolescent mental health problems increasing in the 21 st century? A systematic review. Australian \& New Zealand journal of psychiatry, 2014. 48(7): p. 606-616.

[2] Sue, D.W., et al., Counseling the culturally diverse: Theory and practice. 2019: John Wiley \& Sons.

[3] Rothon, C., et al., Can social support protect bullied adolescents from adverse outcomes? A prospective study on the effects of bullying on the educational achievement and mental health of adolescents at secondary schools in East London. Journal of adolescence, 2011. 34(3): p. 579588.

[4] Noviandari, H. and A. Mursidi, Relationship of Self Concept, Problem Solving and Self Adjustment in Youth. International Journal for Educational and Vocational Studies, 2019. 1(6): p. 651-657.

[5] Santrock, J.W., Adolescence: perkembangan remaja. 2003.

[6] Cui, L., et al., Parental psychological control and adolescent adjustment: The role of adolescent emotion regulation. Parenting, 2014. 14(1): p. 47-67.

[7] Curtis, L.A. and A. Burns, Unit costs of health and social care 2015. 2015: Personal Social Services Research Unit.

[8] McGrandles, A. and K. McMahon, Transition from child and adolescent to adult mental health services. British Journal of Nursing, 2012. 21(17): p. 1031-1039.

[9] Shibutani, T., Society and personality: Interactionist approach to social psychology. 2017: Routledge.

[10]Lopes, M., et al., Genetic yield gains and changes in associated traits of CIMMYT spring bread wheat in a "historic" set representing 30 years of breeding. Crop Science, 2012. 52(3): p. 1123-1131.

[11]Dahl, P., Factors associated with truancy: Emerging adults' recollections of skipping school. Journal of Adolescent Research, 2016. 31(1): p. 119-138.

[12] Wang, M.-T. and J.L. Degol, School climate: A review of the construct, measurement, and impact on student outcomes. Educational Psychology Review, 2016. 28(2): p. 315-352.

[13] Irawan, E., A. Rosidah, and S. Adiputra, Pengembangan Teknik Permainan Dalam Layanan Bimbingan Kelompok
Untuk Meningkatkan Penyesuaian Diri Siswa. Jurnal Fokus Konseling, 2015. 1(1).

[14] Tisdall, E.K.M., Conceptualising children and young people's participation: Examining vulnerability, social accountability and co-production. The International Journal of Human Rights, 2017. 21(1): p. 59-75.

[15] Kunst, M., F. Winkel, and S. Bogaerts, Posttraumatic growth moderates the association between violent revictimization and persisting PTSD symptoms in victims of interpersonal violence: A six-month follow-up study. Journal of Social and Clinical Psychology, 2010. 29(5): p. 527-545.

[16] Corey, G., Theory and practice of group counseling. 2015: Cengage Learning.

[17]Jacobs, A.M., Neurocognitive poetics: methods and models for investigating the neuronal and cognitiveaffective bases of literature reception. Frontiers in human neuroscience, 2015. 9: p. 186.

[18] Rusmana, N., Bimbingan dan konseling kelompok di sekolah (metode, teknik dan aplikasi). Bandung: Rizqi, 2009.

[19] Salgong, V.K., O. Ngumi, and K. Chege, The Role of Guidance and Counseling in Enhancing Student Discipline in Secondary Schools in Koibatek District. Journal of Education and Practice, 2016. 7(13): p. 142151.

[20] Permen PAN RB, N., Tentang Jabatan Fungsional Guru dan Angka Kreditnya. 2009.

[21]Lin, D., C. Barros, and C. Foulkes32, Beyond Insular Education Policy: Learning to live together in the face of climate change in the Pacific. The of Education, 2014.

[22] Permendikbud, N., 24. Kompetensi Inti dan Kompetensi Dasar Pelajaran pada Kurikulum 2013 pada Pendidikan Dasar dan Pendidikan Menengah. Kompetensi Inti dan Kompetensi Dasar Pelajaran pada Kurikulum 2013 pada Pendidikan Dasar dan Pendidikan Menengah, 2016.

[23] Sudrajat, A., Teori-teori motivasi. Tersedia juga dalam http://akhmadsudrajat. wordpress. com/2008/02/06/teoriteori-motivasi/[diakses di Bandung: 9 Oktober 2012], 2008.

[24] Powers, A. and B. Casey, The adolescent brain and the emergence and peak of psychopathology. Journal of Infant, Child, and Adolescent Psychotherapy, 2015. 14(1): p. 3-15.

[25]Chaplin, T.M., Gender and emotion expression: A developmental contextual perspective. Emotion Review, 2015. 7(1): p. 14-21.

[26] Lazarus, R.S., Adjustment and personality. 1961.

[27] De Stefano, N., et al., Evidence of axonal damage in the early stages of multiple sclerosis and its relevance to disability. Archives of neurology, 2001. 58(1): p. 65-70.

[28] Bender, R. and S. Lange, Adjusting for multiple testingwhen and how? Journal of clinical epidemiology, 2001. 54(4): p. 343-349.

[29] Cass, R. and B. Radl, Adaptive process optimization using functional-link networks and evolutionary optimization. IFAC Proceedings Volumes, 1996. 29(7): p. 253-258. 
Sources of funding for research presented in a scientific article or scientific article itself

This article was not funded by any third party and had no any sponsor of it.

Creative Commons Attribution License 4.0 (Attribution 4.0 International, CC BY 4.0)

This article is published under the terms of the Creative Commons Attribution License 4.0

https://creativecommons.org/licenses/by/4.0/deed.en_US 